\section{Research Square}

\title{
An Assessment of Climate Change Response Strategies In The Water Sector In Mutirikwi Sub-Catchment, Masvingo, Zimbabwe
}

Chenjerai Ziti ( $\nabla$ chenjeraiziti@gmail.com )

Great Zimbabwe University

Research

Keywords: water sector, climate change, responses, sustainability, vulnerability

Posted Date: October 5th, 2020

DOI: https://doi.org/10.21203/rs.3.rs-82517/v1

License: (c) (1) This work is licensed under a Creative Commons Attribution 4.0 International License. Read Full License 


\section{Abstract}

The water sector is at the center of climate change impacts matrix. The objective of this study was to determine the sustainability of the response strategies in the water sector in the Mutirikwi sub-catchment in Masvingo. The study obtained its data form surveys recorded meteorological data from the Zimbabwe Meteorological Services Department's four weather stations in the catchment, namely, Makoholi, Masvingo Airport, Buffalo Range and Zaka. Time series analysis of temperature data from 1952 to 2002 and rainfall pattern from 1972 to 2010 was done using the XL STAT software. The results show that the seasonal average rainfall decrease from 1972 to 2010 was not statistically significant $(p=0.635, a=0.05)$, but the decline bears a significant environmental impact. The seasonal maximum temperature increase was statistically significant $(p=0.000, a=0.05)$, and the seasonal minimum temperature increase was not significant $(p=0.226$, $a=0.05$ ). Vulnerability varies spatially within urban areas and between urban and rural. Vulnerability is determined by social status and aggravated by management issues. Borehole use has increased and water harvesting, water reuse and water transfers are the main adaptive responses used in the catchment. The study concludes that current response strategies are not sustainable. There is a need to design area-specific response mechanisms that are all inclusive to ensure that communities are able to adapt to climate change with regard to water resources.

\section{Introduction}

The water sector is susceptible to climate change, where water is the significant medium through which climate change impacts are felt, Droogers et al. [1]. Water is at the center of climate change impacts matrix because of its involvement in all components of the climatic system, Bates et al. [2]; Kusangaya et al.[3]. The impacts on water resources are well documented and Africa is the most vulnerable continent, IPCC [4]. The water sector is still to cope with the changing climate, especially in developing countries as maintained by World Bank [5]. Certainly projected impacts will affect water availability and use and consequently, its management. Climate change affects water resources directly and indirectly through socio-economic and biophysical environments, Bates et al. [1]; IPCC [4]. Responding to the phenomenon requires a holistic approach, which is scenario-based. Progress can be noted on the implementation and studies on adaptation of the water sector in some rural parts of China (Tianjin), India, South Africa, Somalia and Ethiopia (Wilk \& Wittgren [6]; Zhou [7].

Climate change responses are actions taken to "modify the effects of agents of change and effectively reduce consequential vulnerability" Huq [8 p. 1]. Ludi [9] maintained that, there are two broad types of climate change response options that is, mitigation and adaptation. Mitigation involves actions that are aimed at preventing or retarding greenhouse gas (GHG) emissions, South African Development Community (SADC) [10]. On the contrary, Carter cited in Huq [8 p. 12] commented that adaptation is "any adjustment passive, reactive, or anticipatory - that can respond to anticipated or actual consequences associated with climate change." However, Elliot et al. [11] concur with Smit and Wandel [12] that adaptation has taken different definitions depending on the subject of the study. The adopted definition of climate change adaptation in this study is that of IPCC which considers adaptation as the "process of adjustment to actual or expected climate and its effects. In human systems, adaptation seeks to moderate or avoid harm or exploit beneficial opportunities..." [13 p. 118]. Adaptation strategies are determined by the degree of vulnerability, magnitude of change and adaptive capacity of the system to the climate stimuli of the physical systems, natural ecosystems, socio-economic conditions and institutional aspects of the country, Smit and Wandel [12]. Proper adjustment addresses vulnerability and strengthens resilience or adaptive capacity.

Ludi [9] identified two broad types of adaptation, which are planned and autonomous. Under planned adaptation, three strategies are noted in the face of uncertainty; being scenario-based approaches to planning, adaptive management and integrated water resources management (IWRM), Nicol and Kuar [14]. Elliot et al. state that 'no regrets' adaptation strategies are more appealing, which "would generate net social and/or economic benefits irrespective of whether or not climate change occurs" [11 p. 6].

Adaptation to the impacts of climate change on freshwater resources requires both top-down and bottom-up approaches. Ludi, [9] maintained that top-down methods support an assessment of impacts and possible adaptation actions. Bottom-up strategies focus on reducing vulnerability and strengthening resilience to climate change vagaries. Bottom-up analysis identifies the vulnerabilities of the system, factors and conditions that enable successful coping with climate-related threats at different levels of households and communities. SADC [10] advocate that new strategies should be rooted in local and indigenous knowledge. The blending of the two methods is appropriate for adaptation policies and methodologies due to complementarities.

Finlay and Adera [15] categorized adaptation priorities for water into five areas: supply, demand, availability, management and governance. Developing countries are implementing adaptation strategies that are oriented towards the supply and demand side. 
Assessment of these responses is lacking at national and catchment levels, Nicol and Kuar [14]. A concerted effort is noted at the international level to curb the effects of climate change in the water sector and have been dominated by the reduction of greenhouse gases. Adger et al. [16] note that Africa's response to climate change is biased towards adaptation than mitigation. Nilsson and Hammer [17] further stress that increased water stress and demand is due to climate change coupled with population growth, rapid urbanization, industrialization and lifestyle. According to United Nations Environment Programme (UNEP) [18], water in Africa is unevenly distributed, where the Democratic Republic of Congo (DRC) is the most water-rich country in Africa possessing an estimated 52 per cent of Africa's surface water reserves (rivers, lakes and wetlands) and estimated 23 percent of Africa's internal renewable water resources. Kusangaya et al. [3] reiterated the impacts of climate change in the water sector in southern Africa. The poverty and low adaptive capacity of the region increase its vulnerability. Mazvimavi [19] avers that Africa lacks climate literacy- the skill and proper implementation and information dissemination on time for effective responses to climate change.

Zimbabwe's water sector has not been spared by the impacts of climate change. Of late Zimbabwe had no specific policy response to the phenomenon. Chagutah [20 p. 12] puts it that there is no comprehensive, specific national policy and legislative framework for climate change and climate change adaptation. The National Climate Change Response Strategy (NCCRS) was realized in 2012, yet Zimbabwe has been active in the international arena as it signed and ratified the UNFCCC in 1992 and agreed to the Kyoto Protocol on Climate Change in June 2009. Makwara and Tauyanago [21], Dube and van Der Zarg [22], Mapetere et al. [23] note that it is not surprising that Zimbabwean cities to date such as Harare, Bulawayo, Gweru, Kadoma, Mutare and Masvingo face acute water challenges, with some like Norton experiencing "thirst in the midst of the twin lakes", Chigonda [24]. Makwara and Tauyanago [21] further reiterate that Zimbabwean cities are choked with water woes in the midst of plenty. The Zimbabwean water resources are still to be fully developed. There are serious weaknesses in the present water resources planning and management procedures. As a result, Nilsson and Hammer [17] laments that there is a lack of understanding of and institutional facilities for dealing with water in its broader environmental and cyclical context.

Chagutah [20] reports that most of the dams in Zimbabwe have been decommissioned since 2007, with three reservoirs, Muzhwi, Bangala and Mutirikwi being temporarily decommissioned in 2016 Mhiribidi et al. [25]. Climate change has affected ground water recharge and base flow, Davis and Hirji [26], Government of Zimbabwe [27]. Generally, Davis and Hirji [26] note that rates of groundwater recharge are not known, although they have been tried to be quantified by Food and Agricultural Organisation (FAO). They identified two catchmentscale studies, namely Mzingwane and Save catchments, that have modeled the possible impacts of climate change on precipitation and agriculture. In addition United Nations Development Programme (UNDP) [28] applied ten downscaled climate models to the Save catchment to understand adaptation actions for dry land agriculture and livestock farming in the Chiredzi district, Brown et al. [29;30]. Mhiribidi et al. [25] modeled optimal water resource allocation in the southeast low -veld holding Mutirikwi sub catchment at tangent. Studies of the water sector in Masvingo are limited and confined to the Masvingo urban, Dube and van der Zaarg, [22]; Mapfumo and Madesha, [25] and Mapetere et al., [23]. Earlier study by Nilsson and Hammer [17] confirmed that there is insufficient attention to water resources on issues concerning catchment conservation, water harvesting and environmental impacts. Davis and Hirji [26] further point that Zimbabwe's water sector has started to respond to climate change through the construction of dams, policy reforms, establishment of catchment and sub-catchment councils and the National Water Resources Management Strategy. However, according to Mlungisi [31] the responsiveness of the water sector in Zimbabwe has not been proactive at the sub-catchment level. There is no assessment that has made in the water sector regarding its responsiveness to climate change. There is a need for assessment of the current responses, which is the aim of this study, to determine the suitability, applicability, effectiveness and sustainability of the response strategies in the Mutirikwi sub-catchment in Masvingo. This was supported by two sub-objectives:

- To establish the climatic trend of temperature and rainfall in MSC over a forty-year period.

- To determine the response strategies of climate change used in the water sector in MSC, Masvingo.

This study was guided by two research questions.

- What is the trend of climate for the past four decades in MSC Masvingo?

- How sustainable, effective, efficient and relevant are the response strategies and with what success in the water sector to the impacts of climate change in MSC?

\section{Materials And Methods}

\subsection{Study area}


Zimbabwe is divided into 7 catchment areas managed by seven catchment councils and 47 sub-catchment councils, Mhiribidi et al. [25]. The Mutirikwi sub-catchment is found in the Runde catchment in Masvingo Province (Fig. 1)]. It is governed by the Mutirikwi subcatchment Council (MSCC) as per mandate of the reformed Water Act of 1998; which resulted in the establishment of MSCC in 2000.The catchment starts at Serima stretching to Triangle covering districts such as Chiredzi, Gutu, Masvingo, and a small part of Zaka. The mean annual temperature increases from the source to the mouth, ranging between 18 in Chartsworth and 23 in Triangle. The spatial variation of rainfall within the catchment is also witnessed with Gutu receiving much rainfall than Chiredzi. Water users are mainly sugar cane estates in Chiredzi, Triangle, Hippo Valley and Masvingo City. The region is drained by the Chivaka, Munendi, Mutirikwi, Mucheke, Popoteke and Shagashe rivers. Lake Mutirikwi and Bangala dams are major surface water stores with Lake Mutirikwi being the main inland water body after Tokwe Mukosi in the country, Gwazani [32]. Other private water reservoirs are Magudu, Mushavi and Tugwane. Ground water is also used in the catchment.

\subsection{Conceptual framework}

Elliot et al. [11] identified more than eleven adaptation technologies or practices in the water sector. The practices are categorized into six typologies which are diversification of water supply, groundwater recharge, preparation for extreme weather events, resilience to water quality degradation, storm water control and capture and water conservation, IPCC [13]. It should be acknowledged that most practices can fit into more than one typology for the reason that they contribute to more than one aspect of climate change adaptation. Nicol and Kuar [14] noted three intervention mechanisms, namely institutional or policy, technical and market, which address either demand or supply. Presented below is the Table 1 that contextualizes the study.

Table 1

Conceptual framework of climate change responses in the water sector

Typology

\begin{tabular}{|c|c|c|c|c|c|c|c|c|c|}
\hline & & Typology & & & & & & & $\begin{array}{l}\text { sses } \\
\text { nd } \\
\text { ply }\end{array}$ \\
\hline $\begin{array}{l}\text { Type of } \\
\text { intervention }\end{array}$ & $\begin{array}{l}\text { Adaptation } \\
\text { strategy/ } \\
\text { intervention }\end{array}$ & $\begin{array}{l}\text { Diversification } \\
\text { of water } \\
\text { supply }\end{array}$ & $\begin{array}{l}\text { Groundwater } \\
\text { recharge }\end{array}$ & $\begin{array}{l}\text { Preparation } \\
\text { for extreme } \\
\text { weather } \\
\text { events }\end{array}$ & $\begin{array}{l}\text { Resilience } \\
\text { of water } \\
\text { quality } \\
\text { degradation }\end{array}$ & $\begin{array}{l}\text { Storm } \\
\text { water } \\
\text { control } \\
\text { capture }\end{array}$ & $\begin{array}{l}\text { Water } \\
\text { conservation }\end{array}$ & D & $S$ \\
\hline Institutional & IWRM & & & - & - & & - & - & - \\
\hline Technical & Boreholes & - & • & & & • & - & & \\
\hline & $\begin{array}{l}\text { Roof } \\
\text { rainwater } \\
\text { harvesting }\end{array}$ & - & & & & & - & • & - \\
\hline & $\begin{array}{l}\text { Groundwater } \\
\text { harvesting }\end{array}$ & • & & & & - & - & & \\
\hline & $\begin{array}{l}\text { Reuse or } \\
\text { reclamation }\end{array}$ & - & & & - & & - & • & - \\
\hline & $\begin{array}{l}\text { Household } \\
\text { water } \\
\text { storage and } \\
\text { treatment }\end{array}$ & • & & & & & - & & \\
\hline & $\begin{array}{l}\text { Efficient } \\
\text { appliances }\end{array}$ & & & & • & & - & & \\
\hline & $\begin{array}{l}\text { Improved } \\
\text { irrigation }\end{array}$ & & - & & - & - & - & & \\
\hline & $\begin{array}{l}\text { Forest } \\
\text { conservation }\end{array}$ & & & - & & & . & & \\
\hline Market & $\begin{array}{l}\text { Water } \\
\text { meters }\end{array}$ & & & - & & & & - & - \\
\hline
\end{tabular}

\subsection{Research paradigm}

The study adopted post-positivism and constructivism research paradigms. Kivunja and Kuyini [33] note that post- positivism is sometimes referred to as a scientific method; assume that knowledge is objective and quantifiable. The approach described by Mackenzie and Knipe [34] explains experience through observation and measurement in order to predict and control the surrounding forces. In this 
research, the analysis of climatic data (temperature and rainfall) is considered to be post-positivism. The constructivism paradigm is qualitative in nature and deals with subjectivity. The constructivist approach seeks to understand the world of human experience which reality is socially constructed. Under this paradigm, the study relied on the participants' views, experiences and beliefs regarding climate change responses in the context of the water sector, and recognize the impact on the research of their own background and experiences. The use of two research paradigms was necessitated by the need to have more information and meaningful research that uses both qualitative and quantitative approaches.

\subsection{Research design}

A mixed- methods research design was adopted. According to Johnson and Onwuegbuzie [37], this model generally uses separate quantitative and qualitative where the strength of one adds to the strength of the other. Figure 2 below shows the procedure followed using the mixed methods approach.

In this approach, climatic data (temperature and rainfall) and the participants' views and experiences were gathered in separate phases. The mixing of climate data findings and climate change responses was done during data interpretation. Merging of temperature, rainfall and human responses to climate change resulted in well-validated and substantiated research. Creswell [36. p. 213] notes that, "This sideby-side integration is often seen in published mixed methods studies in which a discussion section first provides quantitative statistical results followed by qualitative quotes that support or disconfirm the quantitative results."

\subsection{Sampling and data collection}

The purposive and convenience sampling methods were used to select the participants. As purported by Modal [39] and Mujere [37] purposive sampling is sometimes known as judgmental, selective or subjective sampling. Occasionally known as grab or opportunity sampling is a non-probability sampling method that involves the sample being drawn from that part of the population that is close to the researcher. The study handpicked subjects purposively. Expert sampling was done where the researcher looked for individuals who have particular expertise in water resources management. Mujere [37] puts it that expert sampling is a keystone of a research design and is known as expert elicitation. This implies that the participants were tied to the objectives. The geographical or spatial extent and shape of the study area is elongated, covering four districts of Chiredzi, Gutu, Masvingo, and part of Zaka and was divided into four strata. 200 questionnaires were distributed, with 100 representing rural areas. The purposive and convenience method was chosen because it saves costs and time and allows fast data collection while the integrity and quality of data is maintained, Mujere [37].

In this study, questionnaires were self-administered to the selected respondents with both closed and open questions. All questionnaires administered were retained. The types of information gathered by questionnaires take account of the human's or organizations' level of knowledge, attitude, personalities, and beliefs in response to climate change adaptation in the water sector.

Interviews were carried out with key stakeholders/personnel in the catchments, such as the Mutirikwi Sub-Catchment Council, the Masvingo Town Council and the Chiredzi Rural District Council. Where accessibility was a hindrance, telephone and mail surveys were prompted to key stakeholders. The method provided historical and oral evidence of the phenomenon presented by climatic data recorded at weather stations.

Observations were made during administering and collection of questionnaires and interviews. This method supports the evidence presented by other techniques. From this method, photographs where possible were provided with the consent of the participants.

\subsection{Climate data (temperature and rainfall)}

Meteorological data were obtained from the four weather stations run by the Meteorological Service Department of Zimbabwe namely, Makoholi, Masvingo, Zaka and Buffalo Range. Seasonal mean minimum and mean maximum and total temperature data for weather stations, which span from 1950 to 2000 seasons and for rainfall from 1971/72 to 2009/10. Mean minimum and maximum temperature data were derived from the minimum and maximum daily air temperatures averaged over a year. Two elements (rainfall and temperature) were selected based on the availability of the data as they have a direct effect on the water resources. The data were used to determine the climatic trends and statistical significance of the observed trends.

\subsection{Data analysis and presentation}

In this study, a time series analysis was used to show the trend of climate change and possible implications on water resources. The linear trend line was preferred as it negates seasonality in the time series. Using Excel 2013, the annual average temperature and rainfall for the sub-catchment was calculated using the annual average of the four stations (Buffalo Range, Makoholi, Masvingo and Zaka). The results of the mean annual rainfall were used to reflect the rainfall pattern in the catchment. For temperature, annual minimums and 
maximums from the four stations were averaged to depict the winter and summer scenarios in the catchment. In addition, the total annual average temperature from four stations was found to reflect the annual temperature scenario. Both annual mean temperature (maximum, minimum and annual total) and annual rainfall were then analyzed using XLSTAT Version 2016.02.27554. For the stations with missing monthly data, the annual averages were calculated on the basis of the months with the available data only; however, there was no missing data.

The Mann-Kendall trend test was run to test the data to see that the trend was by chance or occurred in the natural cycle. Pohlert [39] described the Mann-Kendall trend test as a non-parametric trend test that determines whether there is a statistically significant upward or downward change in a time series. The Mann-Kendall trend test has been widely used and tested as an effective method to evaluate the presence of statistically significant trends in hydrological and climatological time series. The software package used in the Mann-Kendall trend test was Excel XLSTAT.

Questionnaires were analyzed for consistency. The results were numerically tabulated in Excel coded and analyzed using SPSS 16.0 software. The findings were discussed and presented as descriptive statistics. Line graphs are useful in illustrating trends over time. Bar graphs were used as they condense large amounts of information for easy understanding in a format that clearly and effectively communicates important points. Images were used to augment the findings.

\section{Results And Discussion}

Figure 3 shows the total seasonal average rainfall pattern in the MSC. The frequency of seasons with rainfall below the normal average is more than the years of above normal average.

The seasons of rainfall below normal average were recorded in 1972/73, 1982/83, 1986/87 and 1991/92. Seasons of notable above normal average rainfall were recorded from 1973 to 1978 and also from 1998 to 2000 . Average rainfall data from 1972 to 2010 were run in a Mann- Kendall trend test in order to determine if the observed pattern was significant. The results show that the decrease in rainfall was not statistically significant $(p=0.635, a=0.05)$. As the computed $p$-value is greater than the significance level $a=0.05$, we fail to accept the null hypothesis. The decrease in rainfall is shown by the negative trend line equation $y=-1.5457 x+640.18$. Using the normal approximation to the distribution of the average Kendall tau the risk to reject the $H_{o}$ hypothesis while it is true was $63.51 \%$. The study affirms the findings of Mudzengi et al. [38].

Although the trend shows no significant change in seasonal total rainfall over time, a declining trend can be observed in Fig. 3. This means that the amount of rainfall is declining although not statistically significant. While the decline is not statistically significant, it still constitutes climate change and may have significant environmental consequences. The declining trend depicts a decrease in the amount of water available in the catchment in time. The reduction in rainfall received raises concerns water availability in the near future. The observation that climate change occurs in this catchment is supported by the findings of Gwazani [32] that water resources are declining in the catchment. Furthermore, farming seasons run short and rainfall is no longer effective, and its period of onset is late November to early December. The results also confirm the findings of Mubvuma [40] that short farming seasons are characterized by droughts in the start and middle of the seasons, making rain-fed agriculture to be difficult. In addition, this concurs with Chikodzi et al. [44], who observed that the catchment is no longer viable for livestock production due to the increase in aridity. Livestock farmers have to do pastoral in February (confirming mid-season drought), thus substantiating the findings of Chibango [42], where drought peaks in January and February in the catchment. The decreasing rainfall proved to bear environmental consequences, which denote the need for proper planning to adapt and mitigate the situation of water scarcity in the face of uncertainty.

Figure 4 shows that summer seasons are becoming warm as depicted by the trend line. Figure 5 shows the minimum annual temperature in the MSC. The results depict that the winter seasons are becoming warm though at a slow rate. The lowest temperature was recorded in 1957; highest temperature was recorded in 1998. The temperature data were tested using the Mann-Kendall test in order to determine if the observed increase in minimum temperature was significant. The results show that the increase in minimum temperature was not statistically significant $(p=0.226, a=0.05)$. We fail to reject $H_{o}$ because our $p$-value is not significant. The increase in minimum temperature is explained by the trend line equation $y=0.0276 x+16.387$. Using the normal approximation of the average Kendall tau, the risk of rejecting the null hypothesis while it is true was $22.58 \%$.

Figure 6 presents the mean seasonal temperature of the catchment. The frequency of seasons with extreme years was recorded from 1954 to 1968 . An extreme low temperature of $15.35^{\circ} \mathrm{C}$ was recorded in 1960 . High temperatures led to the death of animals, depicting the magnitude of the change being witnessed to be high. The Mann-Kendall trend test was run to test data for any significant change. The 
results show that the increase in mean seasonal temperature was statistically significant $(p=0.004, a=0.05)$. We fail to accept the null hypothesis and conclude that the mean seasonal temperature has increased in MSC. The increase in temperature is explained by the trend line equation $y=0.0624 x+20.978$. Using the normal approximation of the average Kendall tau, the risk of rejecting the null hypothesis was $0.45 \%$. Table 2 below summarizes the results.

Table 2

Mann-Kendall test results and interpretation for climate variables

\begin{tabular}{|c|c|c|c|c|c|}
\hline Climate variable & p-value & $\mathbf{a}$ & $\begin{array}{l}\text { Kendall tau } \\
\text { risk of rejection }\end{array}$ & $H_{o}$ Decision & Climate variable trend description \\
\hline Seasonal maximum temperature & $p=0.000$ & 0.05 & $0.04 \%$ & Reject & Increasing with significance \\
\hline Seasonal minimum temperature & $p=0.226$ & 0.05 & $22.58 \%$. & Accept & Declining but not significant \\
\hline
\end{tabular}

The study revealed that there was a positive trend in temperate than in rainfall. This affirms the previous studies of Simba et al., [43; 44] and Chikodzi and Mutowo [45] that the climate of MSC is becoming hotter and drier. The study also revealed that MSC is experiencing water challenges ranging from household to community level. Climate change therefore has implications on water resources causing water demand to be high per capita. Previous researches done by Chikodzi and Mutowo [46] and Mudzengi et al. [38] established that the frequency of droughts is increasing in south eastern Zimbabwe. Local variations in the catchment on climate conditions are noted where other areas are wetter than others. Zaka for instance, is experiencing wetter conditions Chibango [42] while the southern districts are drier Chikodzi and Mutowo [46]. The overall situation of the amalgamated data depicts water deficit for household needs, crop and livestock production and ecological balance.

\subsection{Climate change response strategies in the water sector in MSC 3.2.1 Borehole use}

The study established that $80 \%$ of the households use groundwater through boreholes. The results reflect the boreholes that were drilled to serve community including those at individual homesteads. Of the surveyed boreholes, $60 \%$ were concentrated in rural areas and urban areas constituted $40 \%$ due to piped water supply in urban areas. In terms of distribution, installation of boreholes is skewed in lower part of the catchment (lower part of the Masvingo and Chiredzi districts). This is due to lack of adequate surface water resources emanating from the reduced runoff. The study revealed that $70 \%$ of the boreholes were accessible to households due to their functionality. Access to borehole water depicted by the total functionality of the surveyed boreholes, does not guarantee water security among the households; for a variety of factors are considered such as distance to the water source, duration of service, quality and quantity of water.

The adaptive capacity of the strategy is compromised by technical challenges and lowering of the water table reflecting climate change impact. Technical challenges are attributed to overuse to vandalism. Non-governmental organizations are responsible for capacitybuilding and resilience programmes in the catchment. Women received training on the mechanical aspects of borehole rehabilitation since women are in immediate conduct with water. It was also noted that the borehole strategy reduced its efficiency by a lack of spare parts. From the interviews, the study established that the installation and rehabilitation of boreholes in the catchment is a mandate District Development Fund (DDF) and Zimbabwe National Water Authority (ZINWA), which have down scaled their mandates while the MSCC regularizes the boreholes. The strategy was adopted in both urban and rural areas of the catchment. From interviews and observations, the study established that groundwater in the catchment is saline compared to municipal water. Furthermore, participants reiterated that the hardy water 'annoys' the users when washing. In addition, the locals maintain that borehole water is soap intensive (economically expensive). Moreover, borehole water reduces the efficiency of electrical appliances.

Although the non- functionality is higher, the existing functional boreholes have managed to provide water to the households. The increasing rate of water abstraction may fail the strategy in the near future because the rate of ground water replenishment is decreasing (rate of replenishing is a function of rainfall).

\subsubsection{Roof rain water harvesting}


The study observed that about $62.5 \%$ of the households in the catchment, both urban and rural households practice or use the rain water harvesting method. For example, insert 2 explains the idea of water harvesting. The challenge faced by the users is that they lack the capacity to harvest and store large volumes of water, but rather harvest it for instant use, serving at least 2 days to a week. Dishes and buckets were observed to be the dominant materials used to harvest and store water. Limited households were noted to have mega storage tanks and drums that store water for a month. Harvested water is used for domestic purposes such as toilet flushing, washing, drinking and cooking. The interviews established that harvested water received no additional treatment, but rather the users opted for making tea and cooking in general, where boiling is regarded as the treatment process. Urban residents have adopted it as an alternative source where council water is unreliable. Furthermore, it was reviewed that roof rain water is more preferred to borehole water because of its softness. Economic wise the strategy is regarded as viable.

\subsubsection{Storage facilities}

The storage facilities depend on the social status of households. Households with better income have managed to install mega tanks. Furthermore, the study maintained that those with storage tanks reside in low-density environs such as Morningside and Rhodene in Masvingo urban. The noted storage facilities are used to store both rain water harvested and borehole water. With reference to insert 1 and insert 2 different sizes of containers are noted to be used for water storage in households. It was also reviewed that the mega tanks of harvested water augment borehole water and it is used in the case of emergency; thus, it serves a long period compared to buckets that are for temporal and instant use.

\subsubsection{Water Reuse/ reclamation}

The findings show that reuse or reclaiming water is not widely adopted. Reclaimed water is water which can serve another purpose after it has been used for its primary use. The reclaimed water is used by residents for irrigating home gardens and toilet flushing. The reclaimed water is obtained after washing dishes and clothes. The use of gray water is conditioned by the failure of piped water supply system. Mapetere et al. [23] advised used of water effective flushing system in urban toilets which this study noted as alternative use. Much of the municipal reclaimed water is used for irrigating pastures at Carswell Meats farm in Masvingo.

\subsubsection{Surface storage}

The study established that $30 \%$ of the participants acknowledged their dependence on surface water. This strategy involves harnessing of ground or surface water through natural or artificial reservoirs. It was observed that surface reservoirs in communal lands are important for watering livestock and brick molding. Individuals with surface storage were noted in Morningside and Triangle. In Triangle the harvested waste water from sugar cane plantation is used for horticulture in the resettlement area. The strategy is practiced at low lying areas where excess water drain out of the fields. The sustainability of the strategy is compromised by reduced rainfall received in the area. Implications of this situation is that of coexistence and acceptance of the affected communities within the catchment, competition for water is likely to trigger conflicts where farmers had to adapt to climate change through surface storage facilities. Overgrazing in receiving communities may trigger environmental degradation worsening the water situation where wetlands are encroached to save both humans and livestock. Climate change is affecting the strategy where interviews and observations establish that the water holding capacity of the strategy cannot serve long period due to siltation and high evaporation. Participants echoed that household surface water harvesting sustain households during the rainy season till the start of winter seasons, reflecting low level of sustainability. The results substantiate those of Chikodzi and Mutowo [48] where surface water resources including wetlands are shrinking due to increase in temperature and land use change.

\subsubsection{Inter-basin water transfer}

Interviews with water resources managers from Chiredzi Rural District Council Environmental Engineering department and Ministry of Agriculture, Mechanization and Irrigation Department and MSCC, reviewed that water transfers allow water deficit regions to acquire it from regions with excess. In the catchment, it was noted that the water transfer strategy is practiced at major catchment level that is from Save catchment to Runde catchment. Rather within the catchment users are allowed to use water from other rivers within the catchment. Interviews established that not inter basin transfers per se is practiced in the catchment; but rather MSC distribute or 'feed' water into Chiredzi Sub-Catchment and Lower Runde Sub-Catchment when it has received better rainfall than the other catchments. The strategy has managed to provide water for irrigation to farmers in Triangle and Hippo Valley which draw their water from the three catchments. For the fact that inter-basin transfer is practiced at major catchment level, water woes for the households have not been fully addressed. However, the strategy managed to remedy hydro-ecological imbalances caused by the climate change.

Figure 7 above shows the effectiveness of climate change response strategies expressed as a percentage. It is shown that boreholes constitute $80 \%$ of functionality. This implies that the catchment will have water insecurity in the near future due to low recharge and high 
abstraction. Hand drilled boreholes will dry first causing high population to have no access to ground water. Household storage has a low of $12.5 \%$ which may increase in future as water scarcity increases. This strategy is a function of social income causing water inaccessibility to be high. Roof rain water harvesting is at $60 \%$. The strategy may increase its rate of adoption as households experience water scarcity; however, it depends on income and size of residential stands in urban environs. Reuse practices with a low of $15 \%$ implies that, households still have other response options but may increase as water accessibility decrease.

Surface storage considers $85.7 \%$ in terms of functionality implying that the strategy can be compromised due reduced rainfall input and high temperature. Thus the catchment is not water secure as the non-functional strategies will increase in total percentage. The findings of land use change were not quantified.

\subsubsection{Diversified farming and land use change}

Interviews maintained that livestock farmers in the catchment used to migrate seeking for pastures (pastoral). It was reviewed that there is need to destock aged cattle and adopt the small livestock like goats. However plant species have not been spared by the phenomenon. The study conducted by Chapungu and Nhamo [47] reported that changes in climate variables matched with a decrease in vegetative species richness. Some plant species changed in phenology, abundance and distribution as they succumb to the environmental changes emanating from climate change. In Morning Side, a peri-urban settlement, it was identified that locals in the 1980s were only allowed to have dairy cattle which graze within the premise of individual. However, due to decline in rainfall and water for irrigation the locals adopted drought resistant livestock. Tree conservation is limited within the catchment. Extensive fields are being opened up (near Buffalo Range for sugar cane production) together with resettled farmers who are opening up new fields. In this case there is need to intensify underutilized land than to open up new fields. Agro-forestry is practiced at limited rate in resettled and communal areas. High temperature in the catchment cause planted and juvenile trees to die. The issue of tree loss is aggravated by the droughts which affect vegetation regeneration.

\section{Conclusion}

The objective of the study was set to assess the climate change responses in the water sector used in the MSC. The assessment sought to determine the sustainability, effectiveness and applicability of the responses in the case of decreasing rainfall over a forty year period. The study shows that climate is changing in the catchment where seasonal temperature is increasing in both winter and summer. The increase in temperature is statistically significant. Rainfall decrease is not statistically significant. Although rainfall decrease is statistically not significant, it bears environmental implications.

Climate change in the MSC has caused the length of growing season to run short with late onset of rainfall characterized by droughts. The change manifested through alteration of rainfall distribution, reduced runoff of rivers and groundwater recharge. Increase in temperature has caused high evaporation rate resulting in shrinking of surface storages like Lake Mutirikwi. Households have lost livestock because of droughts and vulnerability has increased.

The study revealed that autonomous adaptation is the main response strategy option in the catchment molded by institutional and market based responses addressing demand and supply. Identified and assessed response strategies include use ground water, roof and surface rain water harvesting, household storage, land use change and post construction support system. Nearly all households in the catchment feel that climate change is impacting water resources. Lack of social security is attributed to low income, failure of rain fed agriculture and livestock production. The failure resulted in land use change and diversification; however, households still do not enjoy any security.

The study concludes that climate change responses in the water sector practiced in the MSC are no longer appropriate, effective and applicable; thus compromising the sustainability of the strategies. Adjustment of the strategies makes them sustainable. It is better to adopt water conservative strategies now when we still have an option than to be forced to do it by scarcity in the near future.

\subsection{Recommendations}

Given the current and predicted ramifications of climate change on water resources in the MSC, this study recommends more research for other existing catchments and sub-catchment in the country. There is still paucity in scientific study on climate change and water sector. The climate change vagaries on other meteorological variables besides temperature and rainfall should also be investigated. Other effects of climate change on future water demand as well as impact of non-climatic variables such as pollution, population upsurge and 
land use activities should also be studied. A comprehensive assessment of how climate change would affect the country's future water resources is recommended too.

In addition there is need scientific of study on the hydro-geological potential of the underlying aquifers. Such studies can be aided with Geographical Information System (GIS) and Remote Sensing. Effective local participation allows synthesis of local and scientific knowledge.

The study also recommends use of pre-paid water meters which place actual economic value on water (user pays principle). From water resources management perspective, prepaid water meter is a viable strategy for water budgeting, ensuring accountability, known quantity abstracted and bills transparency. Therefore, the use of water meters will allow households and famers to do water budgeting knowing how much they pay for water in time than depending on estimations. One of the locals pointed out that piped water is a result of process which does not come for free; hence people will be paying for the service rather than buying water. However, the prepaid water meter should allow out flow of allowed free water (individual basic water) whether the user has paid or not since people have the right to water which is agitated by human rights activists.

In the face of uncertainty, the difficult question is how to increase supply when actual rainfall is decreasing. Demand-based solutions offer better economic returns with limited ecological and social damage. There is need to refurbish existing water infrastructure such as boreholes and water meters. In the face of uncertainty, no regrets options are advisable. All options should be howsoever be rooted in Intergrated Water Resources Management (IWRM).

The study was set to assess the climate change responses in the water sector used in the MSC. The assessment sought to determine the sustainability, effectiveness and applicability of the responses in the case of decreasing rainfall over a forty year period. The study shows that climate is changing in the catchment where seasonal temperature is increasing in both winter and summer. The increase in temperature is statistically significant. Rainfall decrease is not statistically significant. Although rainfall decrease is not statistically significant, it bears environmental implications.

Climate change in the MSC has caused the length of growing season to run short with late onset of rainfall characterized by droughts. The change manifested through alteration of rainfall distribution, reduced runoff to rivers and groundwater recharge. Increase in temperature has caused high evaporation rate resulting in shrinking of surface storages like Lake Mutirikwi. Households have lost livestock because of droughts and vulnerability has increased.

The study revealed that autonomous adaptation is the main response strategy option in the catchment molded by institutional and market based responses addressing demand and supply. Identified and assessed response strategies include use ground water, roof and surface rain water harvesting, household storage, land use change and post construction support system. Nearly all households in the catchment feel that climate change is impacting water resources. Lack of social security is attributed to low income, failure of rain fed agriculture and livestock production. The failure resulted in land use change and diversification; however, households still do not enjoy any security.

The study concludes that climate change responses in the water sector practiced in the MSC are no longer appropriate, effective and applicable; thus compromising the sustainability of the strategies. Adjustment of the strategies makes them sustainable. It is better to adopt water conservative strategies now when we still have an option than to be forced to do it by scarcity in the near future.

\section{Recommendations}

Given the current and predicted ramifications of climate change on water resources in the MSC, this study recommends more research for other existing catchments and sub-catchment in the country. There is still paucity in scientific study on climate change and water sector. The climate change vagaries on other meteorological variables besides temperature and rainfall should also be investigated. Other effects of climate change on future water demand as well as impact of non-climatic variables such as pollution, population upsurge and land use activities should also be studied. A comprehensive assessment of how climate change would affect the country's future water resources is recommended too.

In addition there is need scientific of study on the hydro-geological potential of the underlying aquifers. Such studies can be aided with Geographical Information System (GIS) and Remote Sensing. Effective local participation allows synthesis of local and scientific knowledge. 
The study also recommends use of pre-paid water meters which place actual economic value on water (user pays principle). From water resources management perspective, prepaid water meter is a viable strategy for water budgeting, ensuring accountability, known quantity abstracted and bills transparency. Therefore, the use of water meters will allow households and famers to do water budgeting knowing how much they pay for water in time than depending on estimations. One of the locals pointed out that piped water is a result of process which does not come for free; hence people will be paying for the service rather than buying water. However, the prepaid water meter should allow out flow of allowed free water (individual basic water) whether the user has paid or not since people have the right to water which is agitated by human rights activists.

In the face of uncertainty, the difficult question is how to increase supply when actual rainfall is decreasing. Demand-based solutions offer better economic returns with limited ecological and social damage. There is need to refurbish existing water infrastructure such as boreholes and water meters. In the face of uncertainty, no regrets options are advisable. All options should be howsoever be rooted in Intergrated Water Resources Management (IWRM).

\section{Declarations}

\section{Availability of data and materials}

All data generated or analyzed during this study are not available. Climate data is available. Peoples' responses are not available as the data was captured during Honors level.

\section{Competing interests}

The author declares that I have no competing interests as this was solo project conducted during honours level.

\section{Funding}

The study was not financed by any public or private, profit or non-profit organisation. The researcher gathered data according to available financial resources supported by his mother Mrs. Zviiteyi Chote as she financed my academic pursuits.

\section{Authors' contributions}

Chenjerai Ziti is the sole contributor of the research.

\section{Acknowledgements}

The author wishes to thank Dr. Chapungu, $\mathrm{L}$ and Dr. Zinhiva, H. for their generous support and guidance during the course of this work. My gratitude is extended further to my mother, Mrs. Zviiteyi Chote, who financed my academic pursuits including this project. She offered tremendous parental support. I also acknowledge the input of Abigail and Phenious Ziti. I also thank the participants for their cooperation in sharing with me their views and experience on climate change - water related issues. The input of my colleagues who critique my work to perfection is recognized, particularly Norman Runesu and Raymond Karidza. Mr. Vulindlela Vundla this is for you, your inspirational laughs pushed me forward. To the Almighty thank you for the spiritual guidance and strength for me to excel through my academic pursuits. For without Him I can do nothing.

\section{References}

1. Droogers P, Soet M, van Schaik H. Discussion note to develop an OECD Policy guidance on: Integrating climate change adaptation into development co-operation for the water sector. Future Water: The Netherlands. 2010.

2. Bates B, Kundzewicz ZW, Wu S, Burkett V, Doell P, Gwary D, Hanson C, Heij B, Jiménez B, Kaser G, Kitoh A, Kovats S, Kumar P, Magadza CHD, Martino D, Mata L, Medany M, Miller K, Arnell N. Climate Change and Water. Technical Paper of the Intergovernmental Panel on Climate Change. 2008.

3. Kusangaya S, Warburton ML, van Garderen EA, Jewitt GPW. Impacts of climate change on water resources in southern Africa: A review. Journal of Physics Chemistry and Earth. 2013. 
4. Intergovernmental Panel on Climate Change (IPCC). Summary for policy makers. In: Climate change 2007: impacts, adaptation and vulnerability. Contribution of Working Group II to the Fourth Assessment Report of the Intergovernmental Panel on Climate Change, ML Parry. 2007.

5. World Bank. Climate change impacts on water resources and adaptation in the rural water supply and sanitation sector in Nicaragua. Latin America and Caribbean Region Environment and Water Resources occasional paper series; World Bank. 2013.

6. Wilk J, Wittgren HB (edn.). Adapting water management to climate change, Swedish Water House Policy Brief Number. 7. 2009.

7. Zhou Y. Vulnerability and adaptation to climate change in North China: the water sector in Tianjin. Research unit Sustainability and Global Change, Hamburg, Germany. Undated.

8. Huq S, Karim Z, Asaduzzaman M, Mahtab F. Vulnerability and adaptation to climate change for Bangladesh, Springer Science +Business Media, Dordrecht. 1999.

9. Ludi E. Climate change, water and food security, Overseas Development Institute (ODI), ODI Background Notes, London, UK. 2009.

10. Sothern Africa Development Community (SADC). Climate change adaptation in SADC: A strategy for the water sector.

11. Elliot M, Armstrong A, Lobuglio J, Bartram J. Technologies for climate change adaptation- the water sector. T. De Lopez (Ed.) UNEP Risoe Centre, Roskilde.2011.

12. Smit B, Wandel J. Adaptation, adaptive capacity and vulnerability, Global Environmental Change. 2006;16:282-292

13. Intergovernmental Panel on Climate Change (IPCC). Climate change 2014: Impacts, adaptation, and vulnerability summary for policy makers. IPCC WGII AR5 Phase 1 Report Launch 31 March 2014.

14. Nicol A, Kaur N. Adapting to climate change in the water sector. Overseas Development Institute.2009.

15. Finlay A, Adera E. Application of ICTs for climate change adaptation in the water sector: Developing country experiences and emerging research priorities. Association for Progressive Communications (APC) and International Development Research Institute (IDRC), South Africa. 2012.

16. Adger WN, Huq S, Brown K, Conway D, Hulmea M. Adaptation to climate change in the developing world. Progress in Development Studies 2003;3:179-195.

17. Nilson A, Hammer A. Study of water resources in Zimbabwe. Swedish International Development Cooperation Agency (SIDA), Stockholm Sweden.1996; 824 ZW96.

18. United Nations Environment Programme (UNEP). Water issues in the Democratic Republic of Congo: Challenges and opportunities. Technical report, United Nations Environment Programme, Nairobi, Kenya.2011.

19. Mazvimavi D. Climate change, water availability and supply. In: Kotecha, P. (Ed.), Climate change, adaptation and higher education: Securing our future. SARUA Leadership Dialogue Series 2. 2011;4, 81-100

20. Chagutah T. Climate Change Vulnerability and Adaptation Preparedness in Southern Africa: Zimbabwe Country Report. Heinrich Böll Stiftung, German. 2010.

21. Makwara EC, Tavuyanago, B. Water Woes in Zimbabwe's Urban Areas in the Middist of Plenty: 2000. Present. European Journal of Sustainable Development. 2012; 1, 2, 151-180

22. Dube E, van der Zaarg P. Analysing water use patterns for water demand Management: The case of the city of Masvingo, Zimbabwe. $3^{\text {rd }}$ WARFSA/WaterNet Symposium, Arusha. 2002.

23. Mapetere K, Chigonda T, Chazireni E. Water demand management options in Masvingo City, Zimbabwe. European Journal of Social Science Studies. 2019;4,1,45-56.

24. Chigonda T. Thirst in the midst of the twin lakes: a quest for understanding Norton's ironical water woes. Journal of Sustainable Development in Africa 2011;13, 1: 295-303.

25. Mhiribidi D, Norbert J, Gumindoga W, Rwasoka DT. Optimal water resource allocation modelling in the Lowveld of Zimbabwe. IAHS. 2018; 378: 67-72

26. Davis R. Hirji R. Climate Change and Water Resources Planning, Development and Management in Zimbabwe: An Issues Paper, World Bank.2014.

27. Government of Zimbabwe (GoZ). Zimbabwe National Water Authority Act (Chapter 20: 25), Government Printers, Harare, 1998.

28. United Nations Development Programme (UNDP). Coping with drought and climate change project: A summary report on project achievements (2008-2012). 2012.

29. Brown D, Chanakira RR, Chatiza K, Dhliwayo M, Dodman D, Masiiwa M, Muchadenyika D, Mugabe P, Zvigadza S. Climate change impacts, vulnerability and adaptation in Zimbabwe. IIED Climate Change Working Paper No. 3. 2012.

Page $12 / 17$ 
30. Brown D, Chanakira RR, Chatiza K, Dhliwayo M, Dodman D, Masiiwa M, Muchadenyika D, Mugabe P, Zvigadza S. Climate change responses in Zimbabwe: local actions and national policy, IIED. 2013.

31. Mlungisi N. Adaptation strategies to climate change in the water sector amongst rural communities, Bindura University.

32. Gwazani R. Water level fluctuations and its implications on fish breeding nests in Lake Mutirikwi, Masvingo, Zimbabwe. Journal of Veterinary Advances. 2015,5, 4:863-868

33. Kivunja C, Kuyini AB Understanding and applying research paradigms in education contexts. International Journal of Higher Education. 2017;6,5: 2017.

34. Mackenzie N. Knipe S. Research dilemmas: Paradigms, methods and methodology. Issues in Educational Research. $2006 ; 16$

35. Johnson RB, Onwuegbuzie AJ. Towards a definition of mixed methods research. Journal of Mixed Methods Research. 2007; 1,2: 112133

36. Creswell JW, Plano Clark VL. Designing and conducting mixed methods research. Thousand Oaks, CA: Sage; 2007.

37. Mujere N. Sampling in Research. 2016.

38. Mudzengi BK, Simba FM, Murwendo T, Mdlongwa T. Perspectives in climate change and gender issues: A case study of Masvingo Province, Zimbabwe. Sacha Journal of Environmental Studies. 2013;3,1:1-10.

39. Pohlert T. Non-parametric trend tests and change-point detection. 2016.

40. Mubvuma, M. T. (2013). Climate change: matching growing season length with maize crop varietal life cycles in semi-arid regions of Zimbabwe. Greener Journal of Agricultural Sciences. 2013;3,12:809-816.

41. Chikodzi D, Zinhiva H, Simba FM, Murwendo T. Reclassification of agro-ecological zones in Zimbabwe- the rationale, methods and expected benefits: The case of Masvingo Province. Journal of Sustainable Development in Africa, 2013;15,1:

42. Chibango C. Using rainfall intensity pattern as a signature for climate change in the South Eastern. [Bachelor's Dissertation] Great Zimbabwe University, Unpublished.

43. Simba FM, Murwendo T, Chikodzi D, Munthali, A., Seyitiri, L. Environmental changes and farm productivity: a case study of Masvingo provincein Zimbabwe. Sacha Journal of Environmental Studies, UK, 2012;2,1: 114-129.

44. Simba MF, Mubvuma M, Murwendo T, Chikodzi, D. Prediction of yield and biomass productions: A remedy to climate change in semiarid regions of Zimbabwe. International Journal of Advance Agriculture Research. 2013;1:14-21

45. Chikodzi D, Mutowo G. Drought monitoring for Masvingo province in Zimbabwe: A remote sensing perspective. Herald Journal of Geography and Regional Planning. 2013;2,1: 56 - 60.

46. Chikodzi D, Mutowo G. An analysis of climate change signatures as means of understanding drying up wetlands: A case of Mutubuki wetland in Gutu district of Zimbabwe. Ethiopian Journal of Environmental Studies and Management. 2014;7:821-831.

47. Chapungu L, Nhamo L. An assessment of the impact of climate change on plant species richness through an analysis of the Normalised Difference Water Index (NDWI) in Mutirikwi Sub-Catchment, Zimbabwe. South African Journal of Geomatics. 2016; 5, 2, 244-26

\section{Figures}



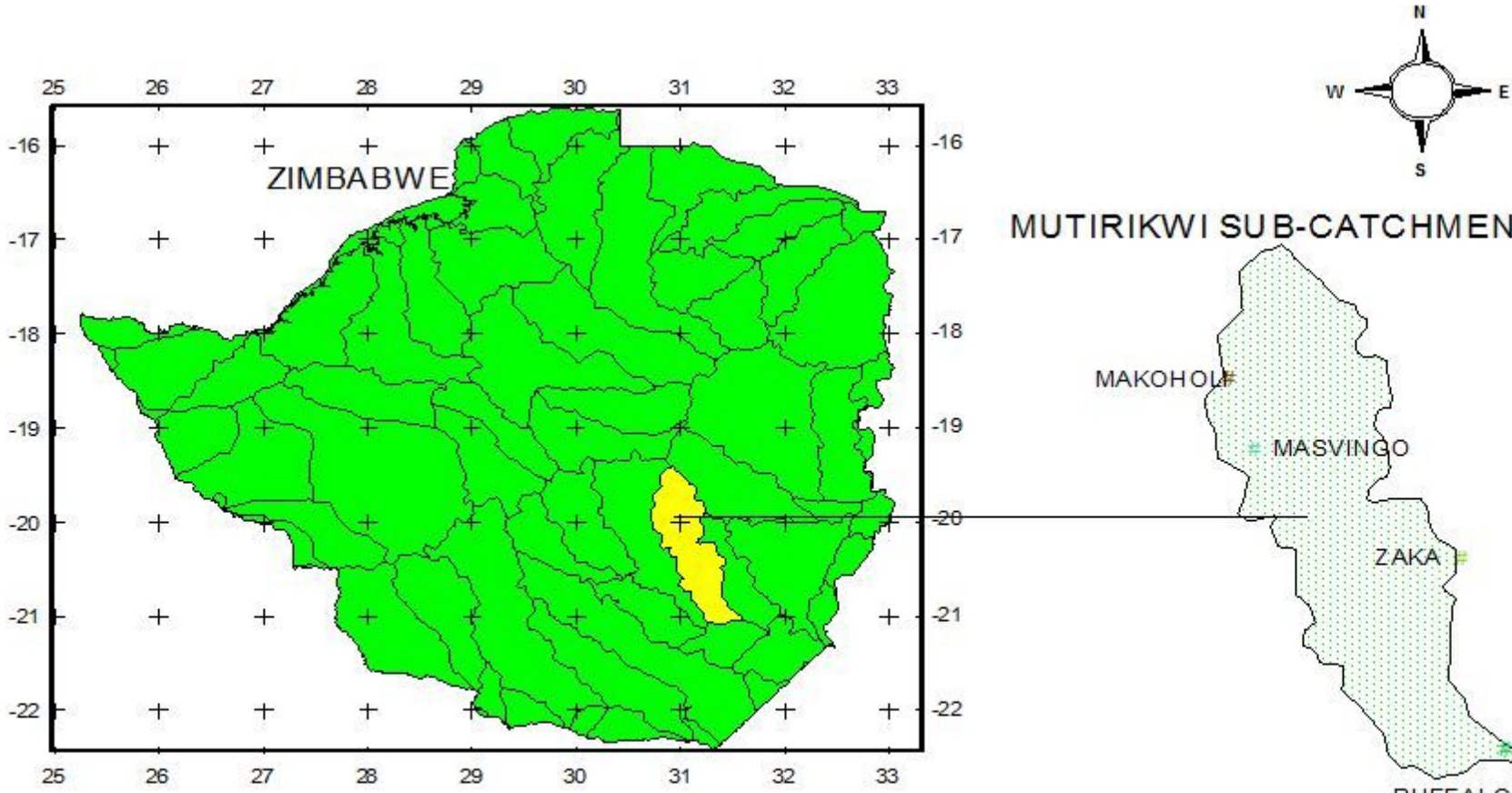

\section{MUTIRIKWI SUB-CATCHMENT}

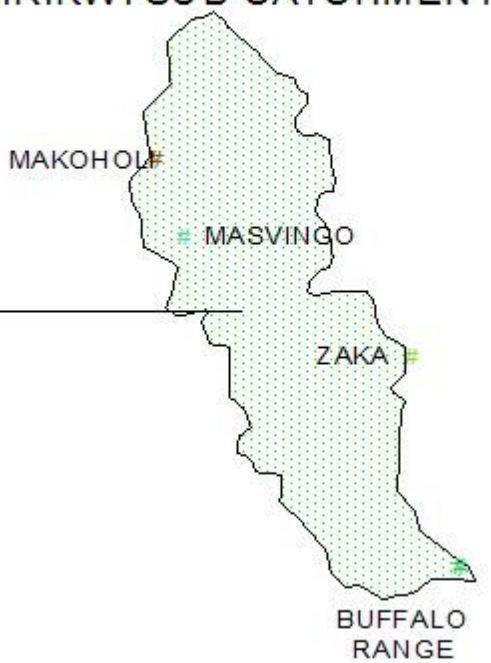

Figure 1

Map of Mutirikwi Sub-catchment

Quantitative Data

Collection:

- Climatic data (rainfall and temperature)

\section{Quantitative data analysis}

- time series analysis

- Data test(MannKendall test)
Qualitative Data Collection:

- Views and experiences on climate change

- Views and experiences on climate change responses on water issues
Qualitative data analysis:

- Content analysis

- Observation analysis

- Attitude analysis

\section{Figure 2}




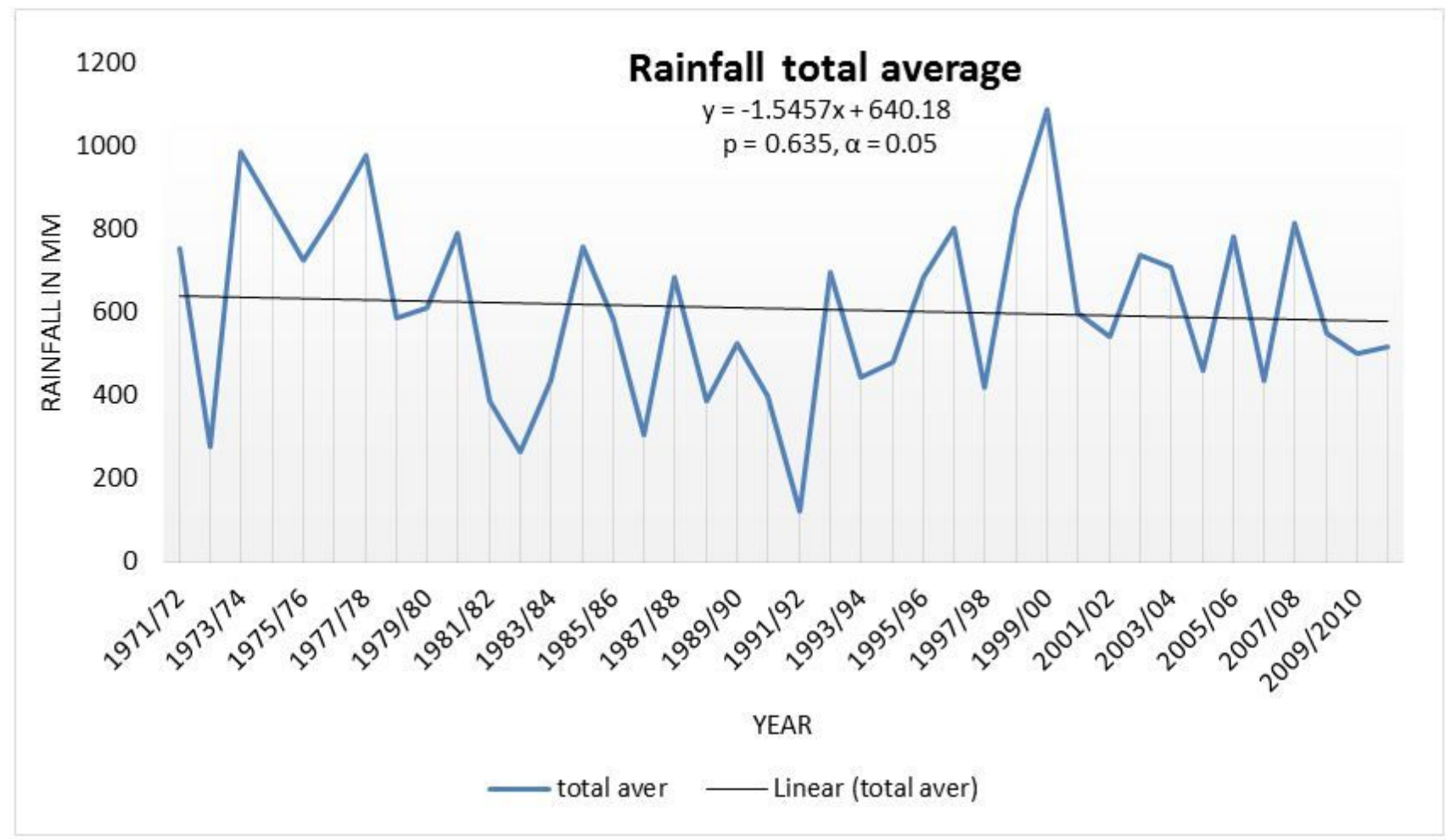

Figure 3

MSC mean seasonal rainfall

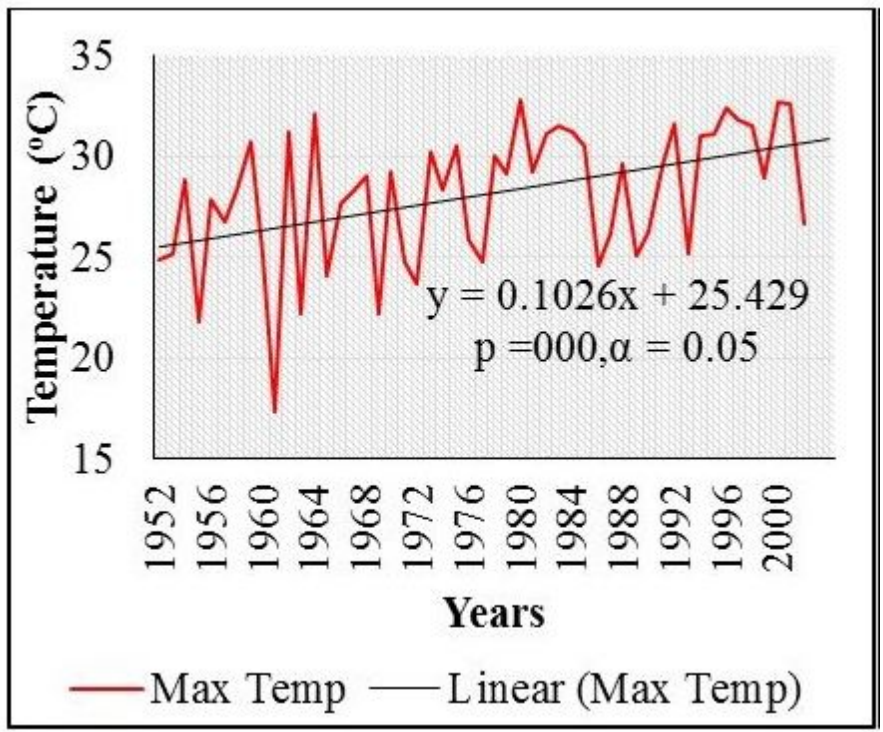

Figure 4

MSC Long term seasonal temperature. Seasonal maximum temperature 


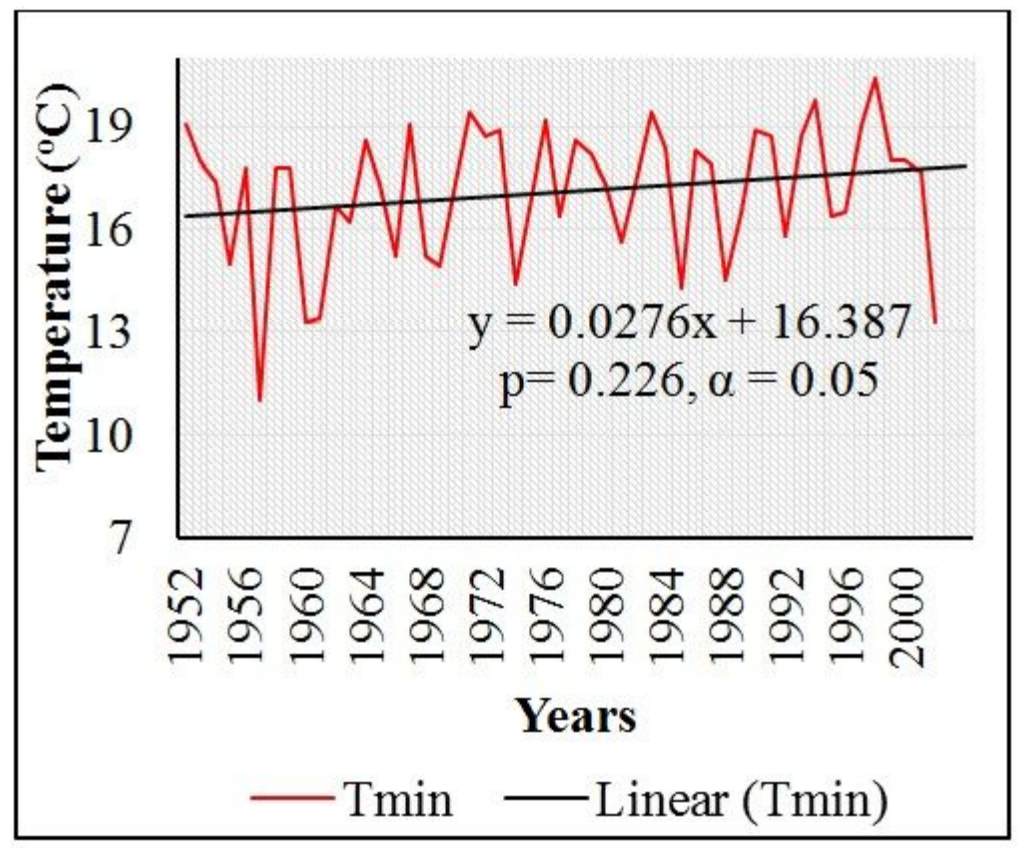

Figure 5

Seasonal minimum temperature in MSC

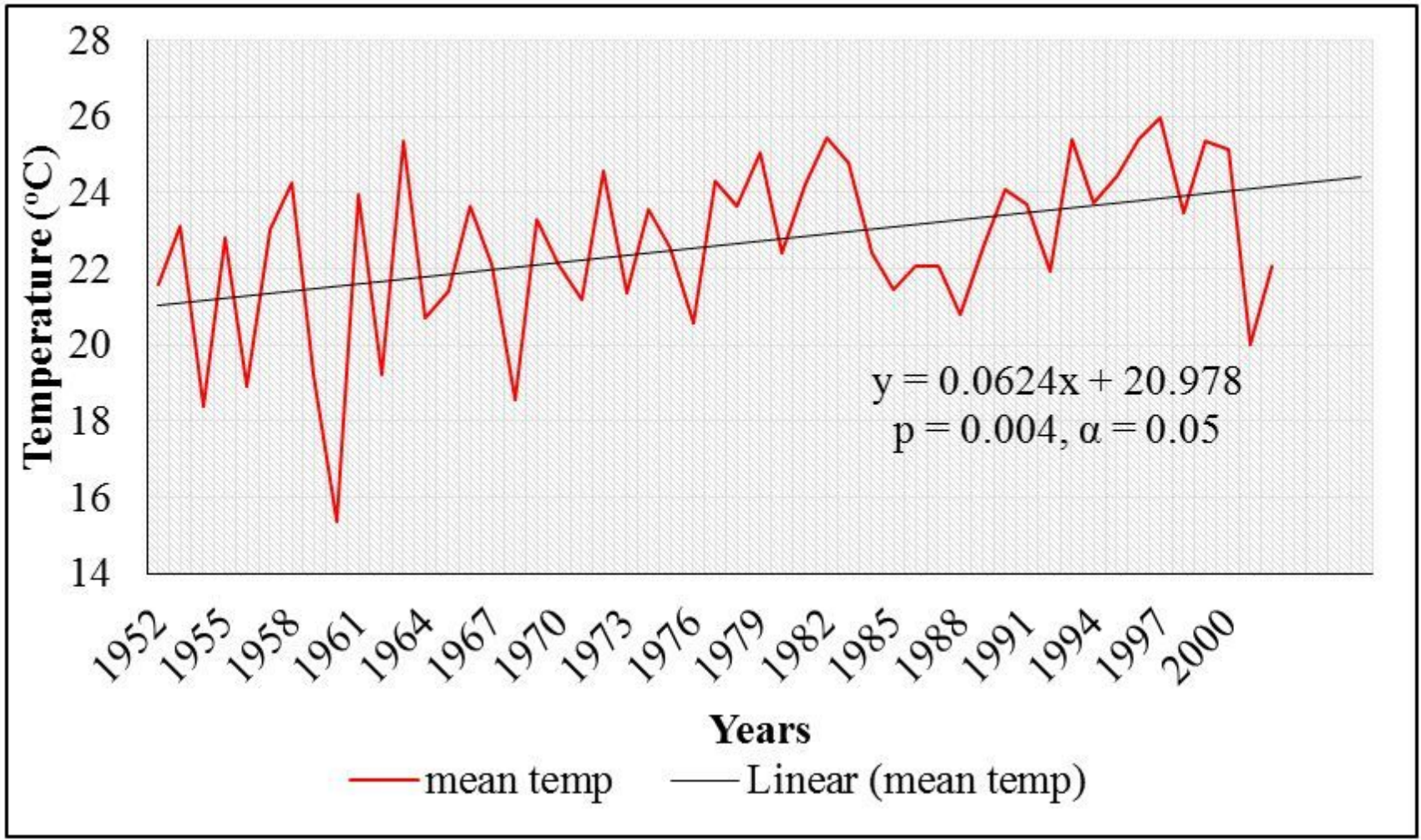

Figure 6

Seasonal mean temperature 


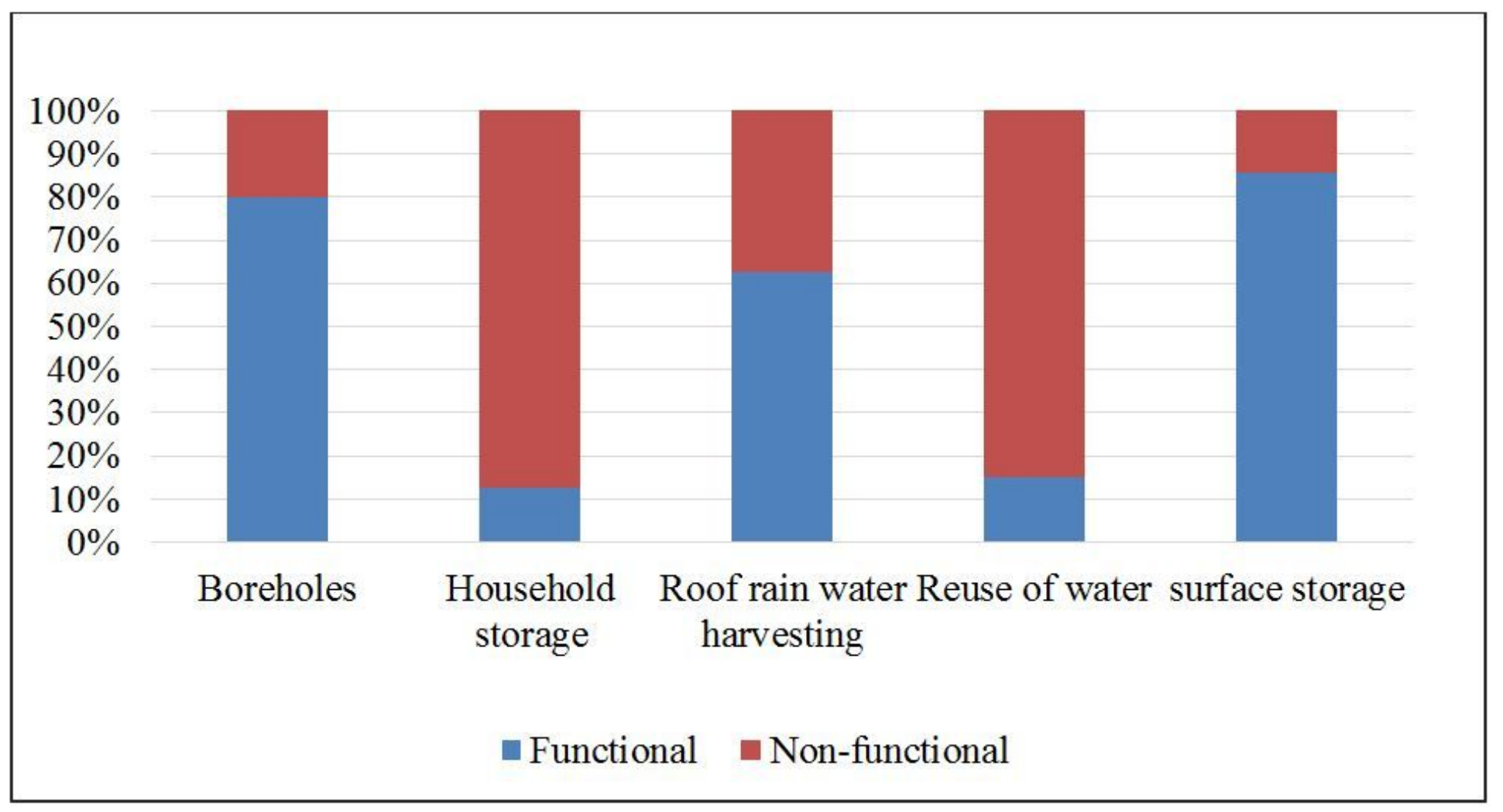

Figure 7

Functionality of climate change response strategies in water sector in MSC.

\section{Supplementary Files}

This is a list of supplementary files associated with this preprint. Click to download.

- climatedatamasvingo.xlsx 